\title{
Mining for medicine - cultivation of medicinal plants as a component of a mine's social responsibility programme in South Africa
}

\author{
J. Botha School of Animal, Plant and Environmental Sciences, University of the Witwatersrand, \\ South Africa
}

\begin{abstract}
The mining industry globally is under increasing pressure to reduce and remediate the high environmental and social costs of their operations from the earliest planning phases. Simultaneously attaining economic, environmental and social objectives requires concerted effort and resources. This paper assesses critical factors that would influence the harvesting and cultivation of medicinal plants on lands owned by mines in South Africa as one element of corporate social responsibility programmes, and highlights the complexities of developing locally appropriate socio-economic projects. Migrant labour has contributed significantly to the economy of South African mines and the country as a whole since the 1890s. To meet the high demand for traditional medicine by this increasingly urbanised labour force, plants valued for their medicinal properties were imported to towns and cities from rural areas, resulting in an extensive trade network spanning the sub-continent which today has evolved into a multi-million rand industry. Subsistence gatherers tend to harvest ("mine") the plants illegally and unsustainably to maximise their returns as there is little incentive to exercise restraint due to the high numbers of people often harvesting from the same sites. This, combined with extensive loss of habitat through development activities, is resulting in the erosion of numerous plant populations and threatening the survival of valued species. Cultivation of this important resource base is not straightforward. Despite the high financial value of the overall trade, medicinal plant products are usually sold at low prices to the subsistence sector. Although traders operating from shops ("amakhemisi") derive relatively lucrative returns, the majority of those trading in the informal sector barely eke out a living, as do the gatherers supplying them. Many medicinal species have a low regeneration rate, resulting in difficulties in attaining financial viability through conventional horticultural or agricultural practices. Access to land for cultivation is also often limited. Many mines have unpolluted tracts of land on which plants could be harvested or cultivated, which could contribute to the health of people and biodiversity conservation, complementing other social responsibility and natural resource management initiatives.
\end{abstract}

\section{Introduction}

Migrant labour has played a vital role in South Africa's mining industry and national economy since the first gold mines were established on the Witwatersrand in the 1890s. Workers were drawn from throughout South Africa and its neighbouring countries (particularly Lesotho), as well as Europe and China, when indentured labourers were transported to the goldfields by mining companies in 1904 (Van Onselen, 2001). Naturally, people came with their own worldviews and belief systems and these were incorporated into the rapidly burgeoning urban settlements.

Traditional medicine has always been an integral part of African peoples' lives, including mine workers (Ballenden, 1933, in Dauskardt, 1991) who daily faced arduous and dangerous working conditions, as well as cramped, crowded and unpleasant living quarters. Elements of traditional medicine have been directly shaped by mining. For example, "blasting gelatine" used as an explosive in the mines was incorporated into magico-medicinal remedies early in the last century (Lewis, 1936, in Dauskardt, 1991). Since the magicomedicinal properties of ingredients used in traditional medicine are often based on the physical attributes of the ingredient (Hammond-Tooke, 1989), these remedies would have been regarded as very powerful. Gold mine tailings (slimes) and seepage from tailings storage facilities are used as substitutes for seawater, and sold for human consumption in Johannesburg and Welkom (I.M. Weiersbye, pers. comm., 2009). 
Just as western medicine has made extensive use of plants and animals, indigenous plant and animals are critical elements of the pharmacopeia in traditional medicine. Over 500 plant species have been recorded in markets in the highly urbanised Witwatersrand in Gauteng Province (Williams, 2003), while 174 species were identified in local markets in Mpumalanga Province, $71 \%$ of the vernacular names encountered in the market place, (Botha et al., 2004). Products are mainly sold as dried bark, roots and bulbs, with lower volumes of dried flowers and leaves. Approximately 19,000 $\mathrm{t}$ of plants are estimated to be traded or used for traditional medicine in South Africa annually (Mander, 1998), with the bulk of this material being collected from the wild. Numerous plant populations are becoming extinct in Mpumalanga Province (Botha, 2001) and KwaZulu-Natal (Cunningham, 1992; Mander, 1998).

This paper assesses the potential of South African mining companies to contribute to the enhanced management of plant species in high demand for traditional medicine as part of corporate social responsibility and mine closure planning. The complexities of integrating the different dimensions of sustainable development at implementation level are highlighted, particularly in a multi-cultural society. The paper draws on research and experience gained during the implementation and assessments of integrated conservation and development programmes by the author, as it is believed that the principles and lessons learned in this context are relevant to others attempting to reconcile the different dimensions of sustainability. All too often, problems experienced during the implementation of projects are repeated in others due to limited sharing of experiences.

\section{Sustainable development in mine closure planning}

The importance of mining to countries' national economies is indisputable. Approximately $4.3 \%$ of South Africa's national workforce were employed in this sector in December 2008, 521,000 people, (Statistics South Africa, 2009a), with approximately 50,000 workers being drawn from neighbouring Lesotho (AIDS and Rights Alliance for Southern Africa, 2008). However, as with the mining sector globally, this contribution has come at high environmental and health costs.

In response to increased pressure from civil society, legislation in many countries requires mining companies to adopt sustainable development principles as an integral component of their codes of good practice, e.g. South African Mineral and Petroleum Resources Development Act, 2002 (Act No. 28 of 2002). It is important to define what different stakeholders understand by this term, as "sustainable development" can range from simply meaning "ongoing (i.e. sustained) development" to rigorous analyses and debate on the different dimensions of the process. The World Commission on Environment and Development (1987) defined sustainable development as:

\section{"... a process of change in which the exploitation of resources, the direction of investments, the orientation of technological development and institutional change are all in harmony, and have both the current and future potential to meet human needs and aspirations".}

The equitable distribution of benefits and resources is a core tenet. The International Council of Mining and Metals (ICMM) identified four dimensions to sustainable development: economic, environmental, social, and governance. Following Choucri (1999), the integrated, dynamic nature of these processes are highlighted in this paper, together with the impact of their outputs on the degree of sustainability attained and subsequent feedback into the cycle. Choucri (1999) also separates out institutions as a key dimension.

In South Africa, holders of prospecting, mining or retention rights or permits must comply with the objectives of integrated environmental management as prescribed by the National Environmental Management Act, 1998 (NEMA) (Act No. 107 of 1998) and:

“...as far as is reasonably practicable, rehabilitate the environment affected by the prospecting or mining operations to its natural or predetermined stage or to a land use which conforms to a generally accepted principle of sustainable development".

Closure planning is now ideally initiated at the earliest stages of development of a mine. Although many companies globally do just enough to meet regulatory requirements, some have successfully managed or remediated the environmental impacts of their mining operations (Finucane, 2008; Sutton et al., 2008). 
Post-mining land use options need to be considered early in the planning process if mining operations are to be implemented in a manner that will increase the probability of sustainable land management once the mine is closed. Closure costs can be contained if mining activities are conducted with long-term consequences in mind, for example, enabling managers to avoid double handling of waste materials by siting them appropriately from the outset (Finucane, 2008).

Mine remediation activities frequently require a combination of technologies, including physical, chemical and biological technologies (Weiersbye, 2007). Plants can be used to stabilise, extract or degrade contaminants occurring in water, waste or soil and to improve the quality of the substrate, broadly termed phyto-technologies, with trees and shrubs being extensively used (ITRC, 2009). The development of resilient vegetation depends on the use of tolerant plants that are able to produce seed despite harsh growing conditions, as well as an adequate quota of biodiversity (Weiersbye and Witkowksi, 2003; 2007). Potential anthropogenic uses of the plants need to be taken into account when selecting species, particularly in developing countries where high proportions of the population depend on plants collected from the wild for building materials, fuelwood, medicines, food and supplementary income generation, etc. (Shackleton et al., 2007). Remediation efforts could be hindered if plant species that are frequently harvested by people or consumed by animals are planted and not protected. In addition, some plants accumulate metals and naturally occurring radioactive materials that could be harmful if ingested in large enough quantities (Steenkamp et al., 2000, 2005; Weiersbye and Cukrowska, 2008).

Effectively integrating the four dimensions of sustainable development into mine and closure management requires concerted effort and resources. Social and community planning issues generally receive less attention than environmental or engineering issues (ICMM, 2006, in Finucane, 2008), although this is changing. Economic considerations still generally dominate the process. A major challenge of closure planning lies in the substitution of alternative income generation opportunities in often mine-based economies as the livelihoods of thousands of employees, and sometimes the economies of whole towns are jeopardised once closure occurs (Chaloping-March, 2008; Hoadley and Limpitlaw, 2008; Mail and Guardian, 2009).

With an official unemployment rate of 23.5\% (4.18 million people) in May 2009 (Statistics South Africa, 2009a), job creation and poverty alleviation have long been critical imperatives for South Africa. Although the economy grew at just over 5\% between 2003 and 2007, the country has experienced structural unemployment for decades. Approximately 50\%, currently about 24 million people, of South Africans live below the poverty datum line of R 354 per month per adult equivalent, with the majority of these having only a few years' formal education (Adelzadeh, 2003; Bhorat and van der Westhuizen, 2008) (US\$ 1 was equivalent to R 6.33 in 2003). State welfare grants such as pensions, child care and health are critical to the survival of most of these households. Over 208,000 people lost their jobs between the last quarter of 2008 and the first quarter of 2009 as the impacts of the global recession reached South Africa (Statistics South Africa, 2009b).

Most South African mining companies have established social responsibility programmes that focus on poverty alleviation through education and skills development projects, some including environmental education initiatives, health programmes, particularly HIV/AIDS and tuberculosis, and small business development. These initiatives are frequently integrated into local economic development (LED) strategies in conjunction with municipalities and other state, business and non-governmental roleplayers.

As an example of socio-economic opportunities generated through phyto-remediation, the University of the Witwatersrand's Ecological Engineering and Phytotechnology Programme contributes to nurseries initiated by entrepreneurs from historically deprived communities through technical and infrastructural support and, even more importantly, by purchasing plants for projects with AngloGold Ashanti Ltd, the Scaw Metals Group, ERGO Mining Pty Ltd (DRD Gold and Mintails), ABB Zinc, Impala Platinum, AngloPlatinum and FreeGold (now Harmony) (AngloGold Ashanti Ltd, 2005, 2009; Scaw Metals Group, 2007, 2009; Impala Platinum, 2009). The nurseries are co-supported by local municipalities, e.g. Kungwini Local Municipality and Metsweding LED, and/or national or regional state agencies such as Department of Water and Environment Affairs, the Gauteng Department of Agriculture and Rural Development, and the Department of Trade and Industry of South Africa. 
In addition to existing social responsibility interventions, mines can also contribute to poverty alleviation and biodiversity conservation in non-monetary ways. Mining companies usually own considerable tracts of land, and people harvest reeds, thatching grass, building materials, food and plants used in traditional medicine illegally on many properties. Control is difficult. Setting up harvesting programmes could reduce risks associated with uncontrolled harvesting and could, in certain instances, be managed to contribute to the mine's remediation programme whilst enhancing harvesters' livelihoods. For example, at AngloGold Ashanti's operations, people are employed to cut-back alien plants and the annual build-up of reeds or inflammable grass adjacent to phyto-remediation sites to prevent fires from killing newly planted tree seedlings. These routinely harvested materials can be used as mulches on tailings dams, or could potentially generate further income for the harvesters through a value-adding process.

Mines could also contribute to the improved management of plants used in traditional medicine, which would meet criteria in each of the dimensions of sustainable development. Firstly, health is a vital issue in most developing countries. With an estimated 5.35 million HIV positive people, South Africa has the highest incidence of HIV/AIDS globally, more than $80 \%$ of whom occur in the economically active age group of 15-49 years (Statistics South Africa, 2009b; UNAIDS, 2006). The rate of tuberculosis infections amongst gold mine employees is also believed to be amongst the highest in the world (South African Department of Health, 2007; AIDS and Rights Alliance for Southern Africa, 2008). Although most South African mining companies have channelled considerable resources to programmes attempting to control these diseases, they continue to severely debilitate the workforce, communities and the economy. Economically deprived communities are also struggling with malnutrition as well as stress and lifestyle associated diseases such as high blood pressure, sugar diabetes, depression, etc. A gap was identified in the health services provided by mining companies to employees and communities globally in that local needs were inadequately understood and continuity of the services provided frequently lapsed after closure (IIED and WBCSD, 2002), although these issues are now being addressed. For example, Palabora Mining Company Limited, through the Palabora Foundation and Richards Bay Minerals in South Africa are encouraging enhanced nutrition by supporting agricultural and horticultural projects, as is Bamangwato Concessions Limited in Botswana.

Secondly, improving the management of traditional medicinal plants contributes directly to biodiversity conservation as many wild plant populations and some species are highly pressurised by intensive harvesting. This is often exacerbated by other anthropogenic pressures such as land fragmentation, disturbance and loss of habitat due to development (Botha, 2001; O'Connor and Kuyler, 2005). In mining regions, water contamination frequently inhibits plant regeneration (Weiersbye and Witkowski, 2007). Thirdly, working effectively with other stakeholders in this sector can develop institutions that extend beyond this initiative. Fourthly, if a pro-poor approach is followed where the focus lies in poverty alleviation, as is recommended in this paper, this initiative could contribute to the poorest sectors retaining access to a critically needed resource, thus contributing to the equity and justice principle of sustainable development.

\section{Traditional medicine in South Africa}

The World Health Organisation estimates that up to $80 \%$ of the populations of African countries still utilise traditional medicine, which is defined as including (WHO, 2002):

“...diverse health practices, approaches, knowledge and beliefs incorporating plant, animal and/or mineral based medicines, spiritual therapies, manual techniques and exercises applied singularly or in combination to maintain well-being, as well as to treat, diagnose or prevent illness."

In South Africa, traditional medicine was generally regarded as backward by the majority of the white population. This view was entrenched by legislation such as the Medical, Dental and Pharmacy Act (No. 13 of 1928), which delineated different disciplines of western medicine but excluded traditional medicine, although provision was made for limited numbers of "native medicine men and herbalists" in the then Natal Province (Dauskardt, 1991). The Witchcraft Suppression Act of 1957 (Act 3 of 1957) and Witchcraft Suppression Amendment Act of 1970 further alienated traditional medicine from the western health paradigm, although its aim was to legislate against the negative consequences of witchcraft. Conservation legislation prohibited the harvesting of many of the plant and animal species extensively used in traditional 
After the democratic transition of government in 1994, traditional medicine has been more widely accepted throughout South African society, although tension is sometimes experienced between traditional health practitioners (THPs) and other members of communities which can lead to conflict and violence (Ralushai et al., 1996; Niehaus, 2001). The private sector now generally acknowledges the extensive reliance of many of their employees on traditional medicine with some granting sick leave if a letter from a registered THP is provided. Several medical aids have integrated traditional medicine as a benefit to members.

Traditionally, THPs and their initiates would harvest the bulk of medicinal species required to treat a patient. Shops selling plant and animal products used for traditional medicine started appearing on the Witwatersrand in the early 1900s to meet demand from the rapidly expanding urban population (Dauskardt, 1991). These products then began to be traded on the streets of Durban, Johannesburg and other cities, as well as in regional and local markets, for example, at monthly pension payout points, providing consumers with easy access to relatively affordable medicinal products as well as generating incomes for thousands of people living on the survivalist end of the economic spectrum. With increasing urbanisation, gatherers started supplying the various market operators with plants harvested from the wild, although some vendors and traders also harvest themselves (Cunningham, 1992; Botha et al., 2004). Many of the shops, known as "amakhemisi" in Zulu, are now owned by Indian traders.

\section{$4 \quad$ Natural resource management interventions}

Most THPs are willing to use cultivated plants and have, historically, cultivated many species to meet their own needs. Numerous medicinal plant cultivation projects have been set up by non-governmental and state conservation and forestry organisations with THPs over the past 15-20 years, but the volume of plant material traded in markets remains high, indicating that people are still harvesting millions of plants from the wild despite these interventions.

Medicinal plant nurseries have been established with THPs in KwaZulu-Natal, Mpumalanga and Limpopo Provinces. These have generally not proven effective, mainly due to the difficulties of producing plants in a nursery at prices that subsistence sector consumers can afford (Botha et al., 2007a). One nursery attained financial viability by switching from the medicinal to the horticultural sector, but none of the 160 THPs in the project received, or were able to buy, plants as they could neither afford the products, nor transport costs to the nursery, despite over R 1.2 million funding. A second nursery failed to achieve financial viability and, after its third year, was costing the group of six THPs substantial amounts of money from their own pockets. Initially, they cultivated plants in their own gardens but this eventually slowed down as most of their efforts were invested in the nursery. At the suggestion of the implementing agency, they started beneficiating locally harvested plant products to enhance their earnings, which contributed to their cash flow but resulted in an increase in their harvesting activities when the original goal was to decrease harvesting from the wild. After seven years, they were still losing money. A third medicinal plant nursery failed when the implementing agency discontinued support after a change in staff, resulting in serious problems for the group, some of whom unsuccessfully attempted to keep the project going over the next 10 years.

THPs have started cultivating medicinal plants in their home gardens through various training initiatives, including two of the above projects as well as through the Silverglen Medicinal Plant Nursery run by the Durban municipality. For example, between 6 and 64 species of medicinal and food plants were recorded in the homesteads of 30 THPs in 1999 (mean $+\mathrm{SE}=36.5 \pm 2.9$ ) (Botha, 2006), the homesteads were usually only about $160 \mathrm{~m}^{2}$ in size. In 2003, a number of THPs reported that they had continued cultivating these plants and no longer harvested from the wild or purchased plants from the markets despite the implementing agency discontinuing support to the project. Whilst effective at a local level, initiatives of this nature have unfortunately made little difference to the volumes traded in the markets, as they are too localised and are being conducted at too small a scale.

\subsection{Market dynamics of the medicinal plant trade}

Potential management interventions cannot be explored without an understanding of market dynamics of the medicinal plant trade. To do so will result in the continued implementation of inappropriate interventions, resulting in wasted resources and high financial and social costs to those THPs who risk participating in these projects. There is also a real probability that the poorest consumers will lose access to this critical 
resource, as many projects focus on adding value to products in attempts to attain financial viability in the absence of a concurrent increase in the resource base, as occurred in the example above. Although beneficiation is a valuable business principle, in this context it is serving to expand the existing market when natural resource managers are unable to meet current demand on a sustainable basis. Plants will continue to be harvested from the wild until populations are so depleted that it is no longer financially viable for gatherers to do so.

Historically, people have paid low prices for medicinal plant products in markets primarily due to the low purchasing power of consumers, but also because people were able to readily harvest plants from the wild either for their own use or to sell. Prices of medicinal plant products sold by informal sector vendors and traders in local and regional markets in Mpumalanga and Limpopo Provinces were mainly determined by the size of the product, with a definite range of unit prices in different size class categories (Botha, 2001). Prices were generally low, with a median of R 5 for products in the 1-99 g size class category in Mpumalanga Province, and R 5 in rural and R 10 in urban markets in Limpopo Province (Botha et al., 2007b). Similarly, $63 \%$ of the products in Faraday market in Johannesburg were sold as R 5 units, and $20 \%$ as R 10 units (Williams, 2003). The perceived availability or scarcity of plants did not influence prices in either Mpumalanga or Limpopo Province. There was a non-significant relationship between perceived demand and price in the latter province, although the utility value of certain plants influenced pricing. For example, higher prices were often charged for species used for anti-social purposes and, sometimes, those used to treat children.

Although some subsistence consumers may be willing and able to pay higher prices for medicinal plants (Mander, 1998), the author watched many turn away when attempting to buy these products in Mpumalanga and Limpopo Province markets as they could not afford them. When asked, almost all the vendors and traders listed the prices consumers were able to pay as a key pricing constraint.

\subsection{Management options}

Improving the management of medicinal plants is challenging as demand far outstrips sustainable availability, and many wild plant populations are located on lands that are difficult to monitor and control. Furthermore, increasing numbers of people are turning to low barrier informal sector income generating activities such as harvesting, or selling wild collected plants in attempts to supplement their livelihoods. People living in rural areas often complain that the foresters and conservation officials who previously patrolled their districts no longer do so (J. Botha, pers. comm., 1999, 2001). This, together with the increasing erosion of authority of many local leadership institutions and high demand for a range of plant products, including those used for fuelwood, building materials, curios, etc., has reduced control of natural resources in many areas.

A further constraint is that many THPs and vendors do not own or have access to land to cultivate plants, particularly in urban areas, as land reform remains a critical socio-economic and political challenge in South Africa. Access to land situated away from homesteads or buildings is also required to grow a number of powerful species that cannot be grown near human habitation as they are perceived to be culturally dangerous but are nonetheless important medicinally. Management options include:

- Improving the management of wild plant populations, where this is feasible, by working with local leadership and gatherers to re-introduce sustainable harvesting techniques. For some species, it may be possible to enhance the regeneration rates of harvested populations by planting truncheons of woody species, or seeds, bulbs and other propagation material derived from the same area to ensure that there is no contamination of the gene pool.

- Allowing THPs, gatherers, vendors and traders access to sites designated for mining, agricultural, urban or other development to collect plant material for cultivation preferably, but also for their own use or selling if sufficient plants are available.

- Granting controlled access to THPs and market operators to harvest fast regenerating species in private and state forestry areas, on private farms, mines and land belonging to other large-scale land owners. 
- Substantially expanding cultivation initiatives at individual and group level with THPs and market operators, although not all traders would be willing to participate.

- Development of herbal supplements as substitutes for plants, which is already occurring. Numerous supplements purporting to contain the ingredients of Warburgia salutaris, Sutherlandia frutescens and other favoured species are being marketed to the more affluent. At this stage, few in the subsistence sector would be able to afford these products.

A multi-pronged strategy is required incorporating management of plant populations in the wild and cultivation. To achieve meaningful social and conservation objectives, a pro-poor approach should be key at this stage, with a fundamental objective being to dramatically bulk up the volumes of cultivated plants as quickly and efficiently as possible, using the existing markets and networks of the THPs and market operators to produce and distribute affordable plants. Attempting to generate profits in projects aiming to provide plants to the subsistence sector is likely to result in the prices of products increasing beyond the reach of the poor without a substantially increased resource base. Although state agencies and nongovernmental organisations (NGOs) are already working with THPs, linkages need to be further developed to more effectively incorporate private enterprise and the gatherers, vendors and traders who sell medicinal products in the markets.

Different stakeholders need to contribute to the process synergistically. For example, state agencies and NGOs could work with individual THPs and market operators to cultivate medicinal plants at the individual, as well as group level (Table 1). It is strongly recommended that projects are developed with existing resource users rather than introducing new stakeholders, such as farmers, to the already complex and competitive sector (Section 3.1).

Projects in different regions could complement each other by growing plants adapted to that region, to maximise cultivation potential. This could be supplemented through harvesting and cultivation initiatives on the properties of large-scale landowners. Market operators need to be included in these processes, as they provide an efficient marketing and distribution service. Regulation and attempts to manage these systems should be avoided. Outside interference in informal sector networks usually disrupts rather than enhances the system, no matter how well intentioned.

Table 1 Integrated approach to effectively bulk up the volumes of plants being cultivated for traditional medicine for the subsistence sector

\begin{tabular}{lll}
\hline Roleplayers & Primary Activity & Secondary Activities \\
\hline $\begin{array}{l}\text { THPs, market operators; } \\
\text { state, parastatal and NGOs; } \\
\text { academic institutions. }\end{array}$ & $\begin{array}{l}\text { Cultivation of plants by THPs on } \\
\text { homesteads and through group } \\
\text { projects. }\end{array}$ & $\begin{array}{l}\text { Develop parallel greening and health } \\
\text { programmes in communities, including } \\
\text { youth }{ }^{1} \text {. }\end{array}$ \\
$\begin{array}{l}\text { Landowners (including } \\
\text { mines), THPs, implementing } \\
\text { agencies. }\end{array}$ & $\begin{array}{l}\text { Access to land earmarked for } \\
\text { development for harvesting. }\end{array}$ & $\begin{array}{l}\text { Work with landowners, THPs, market } \\
\text { operators and implementing agencies to } \\
\text { set up effective, sustainable harvesting } \\
\text { and monitoring systems. }\end{array}$ \\
$\begin{array}{l}\text { Landowners (including } \\
\text { mines), THPs, implementing } \\
\text { agencies. }\end{array}$ & Seeding sites. & $\begin{array}{l}\text { Work with landowners, THPs, market } \\
\text { operators and implementing agencies to } \\
\text { set up effective, sustainable planting and } \\
\text { monitoring systems. }\end{array}$ \\
THPs, market operators. & Distribution and marketing. & $\begin{array}{l}\text { None! As little interference in existing } \\
\text { systems as possible. }\end{array}$ \\
\hline
\end{tabular}

${ }^{1}$ This is critical to minimise jealousies and potential conflicts (Botha et al., 2008). 


\section{$5 \quad$ Potential contributions from mines and other large landowners}

Mines and other landowners could contribute by granting permission for THPs and gatherers to harvest from suitable sites on their properties. Although some sites on mine properties are highly polluted, certain species or plant parts could be harvested or even cultivated (Weiersbye and Cukrowska, 2008), although the bioactive ingredients may need to be assessed in some instances. There are also often some unpolluted areas that could be used for biodiversity conservation and sustainable harvesting from wild populations of medicinal species, for example, dolomitic sinkhole grasslands on Witwatersrand gold mines that are too unstable for agricultural or other development purposes. Mining companies usually map the extent and sites of environmental degradation and pollution as an initial phase in environmental management and mine closure planning strategies, so identification of these sites should be reasonably straightforward. Ongoing monitoring may be required on certain sites, given the mobility of plumes over seasons and with changing biophysical conditions, but again this should be part of existing land management portfolios.

The approach followed will depend on the circumstances of the mine and its neighbouring communities. If people are already harvesting, it is important to identify which species and plant parts are being harvested, in what quantities, from which sites, whether the plants are ingested and to what extent these species are likely to absorb pollutants. Controls and systems need to be set up with the gatherers, in conjunction with the mine's safety and security personnel.

As emphasised thoughout this paper, costs need to be kept as low as possible. THPs prefer plants to be cultivated organically, which negates the need for fertilisers and other expensive inputs. The suggested approach is now discussed in further detail under the different sustainable development dimensions, excluding the economic dimension, which has already been addressed.

\subsection{Ecological and environmental factors}

The project should be incorporated into existing land management and remediation activities, with an emphasis on safe and sustainable land use. The high diversity of medicinal species used in traditional medicine hampers mass cultivation initiatives as economically, it is far simpler and more financially viable to mass produce fewer species. This can be overcome if resource users from different regions cultivate species best suited to local biophysical conditions to enhance regenerative potential. These can then be swapped or sold through existing market and THP networks to enable consumers from different regions to access the wide diversity of species they require.

Some favoured medicinal species are slow growing but others grow relatively quickly, for example, wild ginger (Siphonochilus aethiopicus), the fever tree (Acacia xanthophloea) and pepper-bark tree (Warburgia salutaris). Specimens of these and other species planted in Mpumalanga Province during the development of an integrated conservation and development programme with THPs took approximately four years to reach harvestable size. Depending upon species, indigenous trees planted in AngloGold Ashanti's Mine Woodlands Project are taking between 4 and 20 years (estimated) to reach sizes that could tolerate regular harvesting of leaves, bark or branches (I.M. Weiersbye, pers. comm., 2009). By inter-cropping slower growing species with faster ones and planting on a rotational basis, peoples' needs can be met over time. However, the majority of medicinal species are slow growing when compared with crops from the agricultural sector, where a high turnover is critical to attaining financial viability. The volumes of bulbs that can be produced, or bark or roots that can be harvested off a tree, are also comparatively low.

To bulk up substantial volumes of propagation material rapidly and cost effectively, hardened plugs should be planted out rather than larger seedlings. Where possible, propagation material should be produced through existing projects or nurseries, due to the challenges of attaining financial break even in this sector. This may, however, not always be possible as THPs will naturally want to benefit from potential business opportunities. It is critical to conduct thorough business viability studies before attempting such ventures, however, THPs also need to be aware of the risky nature of the enterprise. 


\subsection{Social}

\subsubsection{Social probe}

A social probe should be conducted prior to the development of the initiative to gain an understanding of the socio-political context in which the local THPs and market players are operating. Social probes can provide a useful understanding of a socio-political environment, or facets of that environment, but are less detailed, time consuming and expensive than social impact assessments. While considerable data is likely to be available from social impact assessments and other reports, it is important to understand the dynamics between the THPs and other local and regional stakeholders, within the context of the broader socio-political and economic environment.

\subsubsection{Cultural protocols}

The use of plants and animals in traditional medicine is governed by strict cultural protocols. Some plants are considered dangerous culturally as they can attract bad luck or lightning, for example, or harm people if correct rituals are not followed. These should not be planted near buildings or other human habitation. Others can culturally "contaminate" other plants by reducing their magico-medicinal healing powers if planted in close proximity, e.g. Stapelia species. Traditionally only men or older women are allowed to harvest plants, and strict rituals are observed for the harvesting of certain species (Cunningham, 1992).

\subsection{Governance}

The Department of Health has been working with THP organisations to establish protocols to improve the quality of services offered to patients. Traditional medicine is now integrated into the national policy and legislative framework, although further work still needs to be carried out. The Traditional Health Practitioners Act (Act No. 35 of 2004) makes provision for the establishment of an Interim Traditional Health Practitioners Council of South Africa, through which THPs will be registered and their practices regulated. The Council is also responsible for promoting health and awareness, setting quality standards and training, as well as developing a Code of Conduct for THPs.

National and regional conservation legislation controlling the harvesting of plants needs to be complied with. The National Environmental Management Biodiversity Act (Act 10 of 2004) regulates the conservation and sustainable use of biodiversity, including regulations to control bioprospecting, access and benefit sharing arising from bioprospecting. Concerns have been raised about the cumbersome process involved in applying for research permits (Crouch et al., 2008).

\subsection{Institution building}

Institution building is often not adequately incorporated into project processes and resourcing, even within implementing agencies mandated to develop poverty alleviation or similar projects, partly because field staff are often over-stretched and/or lack experience and training, and partly because senior management and some donors do not appreciate the need for it. Projects are regularly derailed as a result.

Where possible, it is preferable to link up with existing networks. For example, some municipalities have started working with THPs, e.g. Ekurhuleni Metropolitan Municipality, and it would be advantageous to partner with them to avoid duplication and build on existing institutions.

In impoverished communities, people tend to compete for scarce resources which can lead to serious conflicts over what would seem to an outsider to be simple, low cost development interventions (Botha et al., 2008). These tensions can be heightened with THPs as, although people respect and consult them, they are also feared because of their powers. People are sometimes suspicious of the products THPs use, as some might be used for anti-social purposes. It is thus critical to ensure that projects of this nature are developed in conjunction with community leaders and that other groups receive similar benefits to avoid potential jealousies. For instance, trees, vegetables, attractive medicinal and other ornamental species could be provided for local greening programmes, including schools, clinics and other parts of the community as part of an integrated programme. Information sessions are highly valued in most communities in South Africa, and could include presentations on health, gardening, greening, nutrition, the value of traditional knowledge, 
etc. These endeavours also help build effective communication channels so that should problems arise, they can be swiftly and effectively dealt with.

\section{Conclusions}

Enhanced management of medicinal plants not only contributes to the health of people who rely on these increasingly pressurised species, but also to the conservation of biodiversity. These types of projects can be integrated into existing land management and social responsibility strategies, and enable participating organisations to meet criteria in each of the dimensions of sustainable development. As with any community project it is, however, important to develop systems (including monitoring) with the relevant stakeholders, and to manage the process proactively with relevant partners.

This paper has highlighted some of the complexities in integrating different dimensions of sustainable development into mine closure planning and other corporate social responsibility projects. For example:

- When developing projects, the different dimensions of sustainability need to be understood within the context of the project and stakeholders, and the impacts that this might have on project processes.

- An understanding of markets and other relevant economic factors is crucial. Although the authors like to think the authors have included these in our project viability studies, far too many projects fail due to inadequate planning based on unsubstantiated assumptions.

- Institution building is a critical part of the process, and adequate time, funds and personnel need to be allocated to this.

- Social probes are a useful tool to gain insight into the socio-political context of a potential project. They are cost-effective and can reveal crucial dynamics which may impact on processes and the eventual success or failure of a project. They are not substitutes for social impact assessments, but should complement them.

- A range of solutions to natural resource management challenges need to be generated and assessed, and lessons learned from previous projects. We frequently select the most obvious option without considering alternatives, thinking through potential ramifications or identifying and learning from the experiences of others. This means that the cycles of failure are frequently and unnecessarily repeated, often at great personal costs to the so-called beneficiaries, costs that can undermine peoples' social standing and food security as well as their incomes.

\section{Acknowledgements}

This paper was written as part of the Ecological Engineering and Phytoremediation Programme at the University of the Witwatersrand, Johannesburg and AngloGold Ashanti Ltd, South Africa. The Department of Trade and Industry and the National Research Foundation of South Africa are acknowledged for their long-term support of this programme. The traditional health practitioners, vendors, traders, nursery owners and personnel from implementing agencies who freely shared their knowledge and experiences during the research projects are thanked, as is the Green Trust (WWF and Nedbank) for their support of the research on the medicinal plant markets. The National Research Foundation (NRF2047368 and NRF2053690), the University of the Witwatersrand, and the South African National Biodiversity Institute are gratefully acknowledged for funding research on the nurseries. Isabel Weiersbye and two anonymous reviewers are thanked for their constructive comments that have helped improve this paper.

\section{References}

Adelzadeh, A. (2003) South Africa Human Development Report 2003, The challenge of sustainable development in South Africa, Unlocking people's creativity, United Nations Development Programme (U.N.D.P.), Oxford University Press Southern Africa, Cape Town, South Africa, 246 p.

AIDS and Rights Alliance for Southern Africa (2008) The mining sector, tuberculosis and migrant labour in southern Africa, 19 p., viewed 1 May 2009, http://us-cdn.creamermedia.co.za/assets/articles/attachments/15193_mines\&tb.pdf. 
AngloGold Ashanti Limited (2009) Online 2008 Report to Society of AngloGold Ashanti Limited, accessed 1 May 2009, http://www.anglogold.com/subwebs/InformationForInvestors/Reports08/phyto-remediation.htm.

AngloGold Ashanti Limited (2005) Online 2004 Report to Society of AngloGold Ashanti Limited, viewed 1 May 2009 , http://www.anglogold.com/subwebs/InformationForInvestors/ReportToSociety04/regions/south_africa.htm.

Ballenden, G. (1933) Native customs and conditions, The golden city, Johannesburg, A. MacMillan (ed), Collingridge London, pp. 173-186.

Bhorat, H. and van der Westhuizen, C. (2008) Growth, Poverty and inequality in South Africa, the first decade of democracy, Paper presented at the Development Policy Research Unit Conference, 2008: The Regulatory environment and its impact on the nature and level of economic growth and development in South Africa, School of Economics, University of Cape Town, Johannesburg, 27-29 October 2008, 44 p.

Botha, J. (2006) The viability of conservation and social forestry outreach nurseries in South Africa. Faculty of Science, University of Witwatersrand, Johannesburg, South Africa, $\mathrm{PhD}$, thesis (unpublished).

Botha, J. (2001) Perceptions of species availability and values of medicinal plants traded in areas adjacent to the Kruger National Park, Faculty of Science, University of Witwatersrand, Johannesburg, Master of Science dissertation (unpublished).

Botha J., Witkowski E.T.F. and Cock J. (2008) Plants for Peace? Conflict management in the establishment of ten South African outreach nurseries, Human Ecology, Vol. 36, pp. 485-501.

Botha, J., Witkowski E.T.F. and Cock, J. (2007a) The commercial viability of South African outreach nurseries, Agroforestry Systems, Vol. 70, pp. 135-156.

Botha, J., Witkowski, E.T.F. and Shackleton, C.M. (2007b) Factors influencing the prices of medicinal plants in the Lowveld, South Africa, International Journal of Sustainable Development and World Ecology, Vol. 14, pp. $1-20$.

Botha, J., Witkowski, E.T.F. and Shackleton, C.M. (2004) Market profiles and trade in medicinal plants in the Lowveld, South Africa, Environmental Conservation, Vol. 31, pp. 38-46.

Chaloping-March, M. (2008) Business expediency, contingency and socio-political realities - a case of unplanned mine closure, In Proceedings of the Third International Seminar on Mine Closure, Mine Closure 2008, A.B. Fourie, M. Tibbett, I.M. Weiersbye, P. Dye (eds), 14-17 October 2008, Johannesburg, South Africa, Australian Centre for Geomechanics, Perth, pp. 863-871.

Choucri, N. (1999) The political logic of sustainability, Sustainability and the Social Sciences, A cross-disciplinary approach to integrating environmental considerations into theoretical reorientation, E. Becker and T. Jahn (eds), Zed Books, London, New York, pp. 143-161.

Crouch, N.R., Douwes, E., Wolfson, M.M., Smith, G.F. and Edwards, T.J. (2008) South Africa's bioprospecting access and benefit-sharing legislation, current realities, future complications and a proposed alternative, South African Journal of Science, Vol. 104, pp. 355-366.

Cunningham, A.B. (1992) Imithi isiZulu: the traditional medicine trade in Natal/KwaZulu, Dept of Geographical and Environmental Sciences, Faculty of Science, University of Natal, South Africa, Master of Social Science, (unpublished) dissertation.

Dauskardt, R. (1991) City roots: the emergence of traditional herbalism in Johannesburg, South Africa's informal economy, E. Preston-Whyte and C. Rogerson (eds), Oxford University Press, Cape Town, pp. 88-100.

Finucane, S.J. (2008) Thinking about the end before you start - Integrating mine closure planning into feasibility studies and environmental and social impact assessment. In Proceedings of the Third International Seminar on Mine Closure, Mine Closure 2008, A.B. Fourie, M. Tibbett, I.M. Weiersbye, P. Dye (eds), 14-17 October 2008, Johannesburg, South Africa, Australian Centre for Geomechanics, Perth, pp. 171-182.

Hammond-Tooke, W.D. (1989) Rituals and medicines: Indigenous healing in South Africa, A.D. Donker, Johannesburg, $166 \mathrm{p}$.

Hoadley, M. and Limpitaw, D. (2008) Preparation for closure - community engagement and readiness starting with exploration, In Proceedings of the Third International Seminar on Mine Closure, Mine Closure 2008, A.B. Fourie, M. Tibbett, I.M. Weiersbye, P. Dye (eds), 14-17 October 2008, Johannesburg, South Africa, Australian Centre for Geomechanics, Perth, pp. 845-851.

International Institute for Environment and Development (IIED) and World Business Council for Sustainable Development (WBCSD) (2002) Breaking New Ground: Mining, Minerals and Sustainable Development, Executive Summary, Earthscan Publications, London, 476 p.

Impala Platinum (2009) 2008 Report to Society of Impala Platinum, in preparation.

Interstate Technology and Regulatory Council (ITRC) (2009) Phytotechnology Technical and Regulatory Guidance and Decision Trees, Revised, PHYTO-3, Washington, D.C.: Interstate Technology and Regulatory Council, Phytotechnologies Team, Tech Reg Update, 187 p., viewed 5 July 2009, http://www.itrcweb.org/guidancedocument.asp?TID=63.

Lewis, E. (1936) Johannesburg, Geographical Magazine, Vol. 3, pp. 293-310.

Mail and Guardian (2009) Mooinooi: death of a mining town, Mail and Guardian Online, viewed 12 July 2009 , http://www.mg.co.za/specialreport/mooinooi-death-of-a-mining-town. 
Mander, M. (1998) Marketing of indigenous medicinal plants in South Africa, A case study in Kwazulu-Natal, Food and Agricultural Organisation of the United Nations, Rome, p. 151.

Niehaus, I.A. (2001) Witchcraft, power and politics: exploring the occult in the South African lowveld, Sterling Press, London, $246 \mathrm{p}$.

O’Connor, T.G. and Kuyler, P. (2005) National grasslands initiative: identification of compatible land-uses for maintaining biodiversity integrity, Mining Addendum, South African National Biodiversity Institute, 40 p., viewed 3 June 2009, http://www.sanbi.org/information/reportminingimpact.pdf.

Ralushai, N.V., Masinga, M.V., Madiba, D.M.M., van den Heever, J.A., Mathiba, T.J., Mphaphuli, M.E., Mokwena, M.W., Nolov, V.and Matabane, D. (1996) Report of the Commission of Enquiry into Witchcraft Violence and Ritual Murders in the Northern Province of South Africa, Government of South Africa, 274 p.

Scaw Metals Group (2009), Community Project - Rietfontein Phytoremediation Project, viewed 16 July 2009 , http://www.scaw.co.za/csr_com.php\#3.

Shackleton, C.M., Shackleton, S.E., Buiten, E and Bird, N. (2007) The importance of dry woodlands and forests in rural livelihoods and poverty alleviation in South Africa, Policy and Economics, Vol. 9, pp. 558-577.

South African Department of Health (2007) Tuberculosis strategic plan for South Africa, pp. 2007-2011.

Statistics South Africa (2009a) Quarterly Employment Statistics (QES) December 2008, Statistical release PO277, 38 p., viewed 2 May 2009, http://www.statssa.gov.za/publications/statsdownload.asp?PPN=P0277\&SCH=4410.

Statistics South Africa (2009b) Quarterly Labour Force Survey (QLFS), 1st Quarter 2009, Statistical Release P0211, 45 p., viewed 2 May 2009, http://www.statssa.gov.za/publications/P0211/P02111stQuarter2009.pdf

Steenkamp, V., Stewart, M.J., Chimuka, L. and Cukrowska, E.M. (2005) Uranium concentrations in South African herbal remedies, Health Physics, Vol. 89, pp. 679-683.

Steenkamp, V., von Arb, M. and Stewart, M.J. (2000) Metal concentrations in plants and urine from patients treated with traditional remedies, Forensic Science International, Vol. 114, pp. 89-95.

Sutton, M.W., Pretorius, H., Nel, J.H., Julyan, F. and Rex, H.G. (2008) Closure planning and estimating within the southern Africa division of a global gold miner, In Proceedings of the Third International Seminar on Mine Closure, Mine Closure 2008, A.B. Fourie, M. Tibbett, I.M. Weiersbye, P. Dye (eds), 14-17 October 2008, Johannesburg, South Africa, Australian Centre for Geomechanics, Perth, pp. 145-159.

The United Nations Joint Programme on HIV/AIDS (UNAIDS) (2006) AIDS Epidemic Update, United Nations, pp. $145-159$.

Van Onselen, C. (2001) New Babylon, New Ninevah, Everyday life on the Witwatersrand (1886-1914), Jonathon Ball Publishers, Jeppestown, $487 \mathrm{p}$.

Weiersbye, I.M. (2007) Global review and cost comparison of conventional and phyto-remediation technologies for mine closure, In Proceedings of the Second International Seminar on Mine Closure, Mine Closure 2007, A.B. Fourie, M. Tibbett, J.V. Wiertz (eds), 16-19 October 2007, Santiago, Chile, Australian Centre for Geomechanics, Perth, pp. 13-19.

Weiersbye, I.M. and Cukrowska, E.M. (2008) Elemental concentrations in wild plants and crops on the Witwatersrand Basin gold fields: recommendations for safe land-uses, Manuscript in preparation.

Weiersbye, I.M. and Witkowski, E.T.F. (2007) Impacts of acid mine drainage (AMD) on the regeneration potential of highveld phreatophyte plants, In Multiple Use Management of Natural Forests and Woodlands: Policy Refinements and Scientific Progress IV, J.J. Bester, A.H.W. Seydack, Vorster, T., Van der Merwe, I.J. and Dzivhani, S. (eds), Department of Water Affairs and Forestry of South Africa, pp. 224-237, viewed 5 May 2009 www2.dwaf.gov.za/dwaf/download.asp? $\mathrm{f}=4272$.

Weiersbye, I.M. and Witkowksi, E.T.F. (2003) Acid rock drainage from gold tailings dams on the Witwatersrand Basin impacts on tree seed fate and seedling morphology, In Mine water and the environment VII, D. Armstrong, A.B. de Villiers, R.L.P. Kleinmann, T.S. McCarthy and P.J. Norton (eds), International Mine Water Association, pp. 311-328.

Williams, V.L. (2003) Hawkers of Health: an Investigation of the Faraday Street Traditional Medicine Market in Johannesburg, Gauteng, Plant Ecology and Conservation Series No. 15, Report to the Department of Agriculture, Conservation and Environment (DACEL), $58 \mathrm{p}$.

World Commission on Environment and Development (1987) Our common future, New York: Oxford University Press, $400 \mathrm{p}$.

World Health Organisation (WHO) (2002) Traditional Medicine Strategy (2002-2005), 128 p., viewed 2 May 2009 , http://www.who.int/medicines/publications/traditionalpolicy/en/index.html. 